\title{
Temperature induction of viruses in symbiotic dinoflagellates
}

\author{
William H. Wilson ${ }^{1, *}$, Isobel Francis ${ }^{2}$, Keith Ryan ${ }^{1}$, Simon K. Davy ${ }^{2}$ \\ ${ }^{1}$ Marine Biological Association, Citadel Hill, Plymouth PL1 2PB, United Kingdom \\ ${ }^{2}$ Institute of Marine Studies, University of Plymouth, Plymouth PL4 8AA, United Kingdom
}

\begin{abstract}
Bleaching manifests itself as a loss of symbiotic dinoflagellates (zooxanthellae) and/or chlorophyll from a variety of symbiotic hosts, including corals and sea anemones. Bleaching is known to result from a range of environmental stresses, the most significant of which is elevated temperature; how these stresses elicit a bleaching response is currently the focus of intense research. One consequence of environmental stress that has yet to be considered is viral attack. Here, we have isolated a transferable infectious agent believed to be a virus, from zooxanthellae of the temperate sea anemone Anemonia viridis. The infectious agent is induced by elevated temperature. Once induced, the filterable agent can be further propagated without heat induction, thus fulfilling Koch's postulates. We propose that zooxanthellae harbor a latent viral infection that is induced by exposure to elevated temperatures. If such a mechanism also operates in the zooxanthellae harbored by reef corals, and these viruses kill the symbionts, then this could contribute to temperature-induced bleaching.
\end{abstract}

KEY WORDS: Viruses - Anemones - Coral bleaching · Zooxanthellae $\cdot$ Latent infection

Resale or republication not permitted without written consent of the publisher

Many species of marine invertebrates, such as corals, sea anemones and giant clams, harbor endosymbiotic dinoflagellates (zooxanthellae) in their tissues. Zooxanthellae release short-term photosynthetic products to their hosts and so are an important source of organic carbon for host metabolism, growth and reproduction (Muscatine 1990). Zooxanthellae are also important in the recycling and conservation of essential nutrients, such as nitrogen (Wang \& Douglas 1998), and enhance calcification rates in corals (Davies 1992).

Incidents of coral bleaching, synonymous with the loss of photosynthetic pigments and/or zooxanthellae from the host, have been frequent in recent years (Hoegh-Guldberg 1999). Indeed, the coral bleaching event in 1997 to 1998 was the most geographically extensive and severe in recorded history, and caused significant coral mortality worldwide (Harvell et al. 1999).

*E-mail: whw@mba.ac.uk
Associated with these catastrophic ecological events were widespread socio-economic impacts (Obura 1999, Rajasuriya et al. 1999), leading to tremendous public interest in the causes of coral bleaching (Anderson 1999, Pockley 1999, 2000). Increased seawater temperature has been identified as the major culprit for worldwide coral bleaching events (Harvell et al. 1999). However, the mechanism of thermal disruption is still being determined. Current research has investigated processes such as host cell adhesion dysfunction (Gates et al. 1992), bacterial attack (Kushmaro et al. 1997, Banin et al. 2001) and thermal disruption of photosystems I and II (Iglesias-Prieto et al. 1992, Warner et al. 1999, Jones et al. 2000). However, one potential factor that has not been investigated is viral infection.

The importance of viruses in the marine environment has become increasingly apparent over the last decade (Fuhrman 1999). Concentrations of up to $10^{8} \mathrm{ml}^{-1}$ have been reported (Bergh et al. 1989) and it is thought that most microbial populations in seawater have viruses that infect them. Although most of these viruses are thought to infect bacteria (Wilcox \& Fuhrman 1994), a significant proportion of them are known to infect primary producers, such as Emiliania huxleyi (Bratbak et al. 1996) and cyanobacteria (Wilson et al. 1993), and play an active role in the structuring of planktonic communities (Wilson et al. 1998). In this study, we conducted some simple experiments to determine if viruses are involved in temperature-mediated death of zooxanthellae isolated from the temperate anemone Anemonia viridis.

Methods. Preparation of zooxanthellae: Anemones were collected at low tide from intertidal pools on Batten Bay, near Plymouth, UK. Freshly collected anemones were used for each experiment. They were transferred to a $10 \mathrm{l}$ holding tank at $15^{\circ} \mathrm{C}$, fed by a coarse filtered flow-through seawater system, and piped into the laboratory from seawater off the coast of Plymouth, UK. Illumination was provided on a 16:8 h light:dark cycle from a $150 \mathrm{~W}$ cool aquarium light. 
Zooxanthellae were isolated from anemones by homogenizing up to 12 tentacles in sterile seawater in a tissue grinder. The homogenized suspension was centrifuged at low speed and the supernatant discarded. The process of resuspending the pellet in fresh sterile seawater and centrifugation was repeated until the supernatant was clear of sea anemone debris. Zooxanthellae in the cleaned pellet and subsequent induction experiments were enumerated in a Neubauer improved hemacytometer.

Virus induction and propagation: Zooxanthellae isolated from the anemone were exposed to a heat shock of $32^{\circ} \mathrm{C}$ for a period of $24 \mathrm{~h}$ and then incubated at $15^{\circ} \mathrm{C}$ for a further $7 \mathrm{~d}$. Following this experiment, lysed zooxanthella suspensions were passed through a $0.2 \mu \mathrm{m}$ filter, and $100 \mu \mathrm{l}$ aliquots of the filtrate were added to freshly isolated zooxanthellae, which were then incubated at $15^{\circ} \mathrm{C}$ without heat treatment. During virus induction and propagation, zooxanthellae were incubated in a cooled illuminated incubator (Sanyo) set on a 16:8 h light:dark cycle at the required temperature.

Thin section analysis: Prior to embedding, zooxanthellae were fixed in $4 \%$ glutaraldehyde and $1 \%$ osmium tetroxide. Fixatives were replaced with sterile seawater after low speed centrifugation to pellet the cells. After dehydration through an acetone series of $25,50,75$ and $100 \%$, the pelleted cells were embedded in $\mathrm{TAAB}$ embedding resin (TAAB Laboratory Equipment Ltd.) and hardened at $60^{\circ} \mathrm{C}$ for $48 \mathrm{~h}$. Sections were cut on a Reichert-Jung Ultracut microtome and stained with solutions of uranyl acetate and lead citrate on copper grids. Transmission electron microscopy (TEM) was conducted on a JEOL 200CX operated at $160 \mathrm{kV}$ at magnifications up to $150000 \times$.

Results and discussion. Exposure of zooxanthellae isolated from the temperate sea anemone Anemonia viridis to $32^{\circ} \mathrm{C}$ for a period of $24 \mathrm{~h}$ induced cell lysis; most of the isolated zooxanthellae were killed compared to a $15^{\circ} \mathrm{C}$ control (Fig. 1a). We did observe a decline in numbers in the controls (Fig. 1), however, it is known that zooxanthellae from Anemonia viridis are difficult to culture and rarely survive for more than a few months in isolation (Davy 1994). TEM analysis revealed an abundance of small (40 to $50 \mathrm{~nm}$ ) viruslike particles (VLPs) in the zooxanthella suspensions that had collapsed following heat treatment (Fig. 2). In addition, VLPs of the same size were observed in thin sections of zooxanthellae still harbored by Anemonia viridis, after the anemones were exposed to a gradual increase in temperature to $32^{\circ} \mathrm{C}$ over a $2 \mathrm{wk}$ period (results not shown). It has previously been observed that heat-shock treatment can induce lytic infection of the green alga Cylindrocapsa geminella (Hoffman \& Stanker 1976). Using thin-sectioning and TEM, these workers demonstrated that viral particles ca 200 to
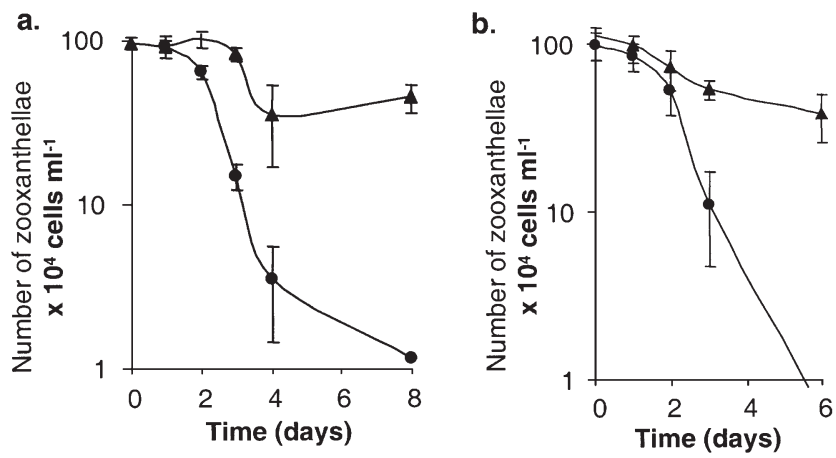

Fig. 1. Induction experiments on zooxanthellae isolated from the sea anemone Anemonia viridis. (a) Changes in zooxanthella density following either heat shock for $24 \mathrm{~h}$ at $32^{\circ} \mathrm{C}_{i}$ (b) or following infection by a filtered aliquot from the heat shock lysate, where complete lysis was observed after $6 \mathrm{~d}$ (final data point not shown). In each experiment, the control zooxanthellae ( $\mathbf{\Delta})$ were incubated at $15^{\circ} \mathrm{C}$ on a $16: 8 \mathrm{~h}$ light:dark cycle. Heat-treated zooxanthellae $(\bullet, a)$ were transferred to control conditions after $24 \mathrm{~h}$. Infected zooxanthellae $(\bullet, b)$ were incubated under control conditions throughout the experiment. Data points are the mean and standard deviation of triplicate counts

$300 \mathrm{~nm}$ in diameter can be produced following a heat shock of $40^{\circ} \mathrm{C}$ for $6 \mathrm{~h}$.

Our results indicated that we had induced a latent virus from the zooxanthellae following the heat shock. We were initially concerned that the results were influenced by heat-induced bacteriophages in the nonaxenic preparation. However, to rule this out, we employed thin-section analysis of infected zooxanthellae (discussed below, Fig. 3).

During a latent infection, a single virus particle incorporates its nucleic acid into host genomic DNA and

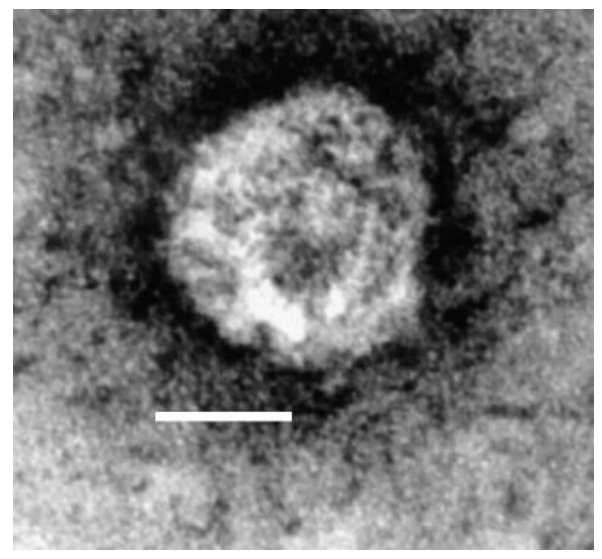

Fig. 2. Transmission electron micrograph of a virus-like particle observed following heat shock treatment of zooxanthellae isolated from the sea anemone Anemonia viridis. Non-concentrated supernatant was viewed, following negative staining with uranyl acetate, from lysed, isolated zooxanthellae which had previously been subjected to a heat induction of $32^{\circ} \mathrm{C}$ for $24 \mathrm{~h}$ then incubated at $15^{\circ} \mathrm{C}$ on a $16: 8 \mathrm{~h}$ light:dark cycle for $6 \mathrm{~d}$. Scale bar $=25 \mathrm{~nm}$ 

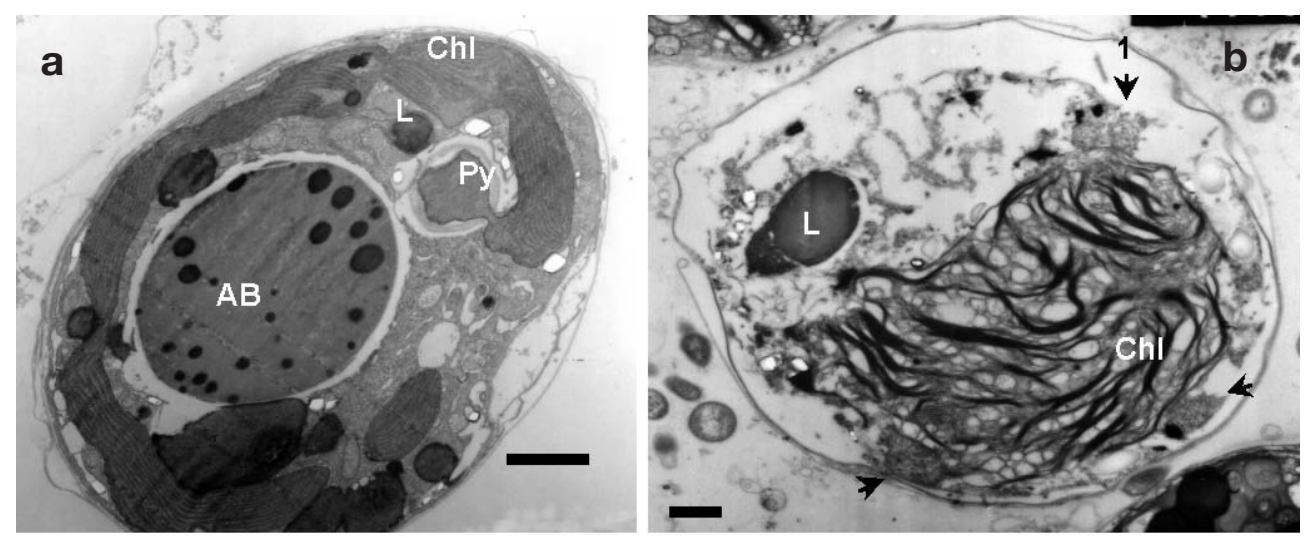

Fig. 3. Thin section transmission electron microscope analysis of zooxanthellae showing the infectious agent thought to be a virus. Thin sections were prepared from isolated zooxanthellae, $6 \mathrm{~d}$ post-infection (same suspension as Fig. 1b) using a $0.2 \mu \mathrm{m}$ filtered lysate as the infectious inoculum. (a) Noninoculated, control zooxanthella, showing no obvious signs of infection. Chl: chloroplast; Py: pyrenoid; L: lipid; AB: accumulation body, scale bar $=1 \mu \mathrm{m}$. (b) Pockets of virus-like particles (VLPs) (viroplasm) can be seen (arrows) in a disintegrating zooxanthella cell, scale bar $=1 \mu \mathrm{m}$. (c) Closer inspection of a viroplasm (from b, arrow 1) reveals that the VLPs are similar in size (45 to $50 \mathrm{~nm}$ ) to VLPs observed in the heat-shocked zooxanthellae (Fig. 2), scale bar $=100 \mathrm{~nm}$

replicates as a provirus over several generations within the host genome. Induction of the lytic cycle usually occurs following exposure of the host to either a mutagenic stimulation such as short wave ultra-violet (UV) light or environmental stresses such as nutrient availability (Scanlan \& Wilson 1999) or, classically, increased temperature (Edgar \& Lielausis 1964). This exposure eventually leads to host cell lysis and further propagation of progeny viruses in susceptible hosts.

To fulfil Koch's postulates, filtered lysed zooxanthella suspensions were added to freshly isolated zooxanthellae, then incubated without heat treatment. Infected preparations started to lyse after $2 \mathrm{~d}$ and substantial lysis was evident after $6 \mathrm{~d}$ (Fig. 1b). Thin section TEM analysis of infected cells (taken on Day 6, Fig. 1b) revealed that pockets of VLPs (viroplasm) were present in dying zooxanthellae (Fig. 3b). VLPs within the viroplasms (Fig. 3c) were similar in size to those observed after the initial heat shock treatment. In contrast, no VLPs were observed in non-inoculated, control zooxanthellae (Fig. 3a). Thus, Koch's postulates were fulfilled; an infectious agent isolated from a diseased host was used to re-infect healthy host cells that subsequently showed the same disease symptoms. However, host cells that harbor a latent infection usually exhibit superinfection immunity, which makes them resistant to further infection. Our results suggest that not all zooxanthellae in this sea anemone harbor a latent infection (otherwise further propagation of the virus would not have been possible).

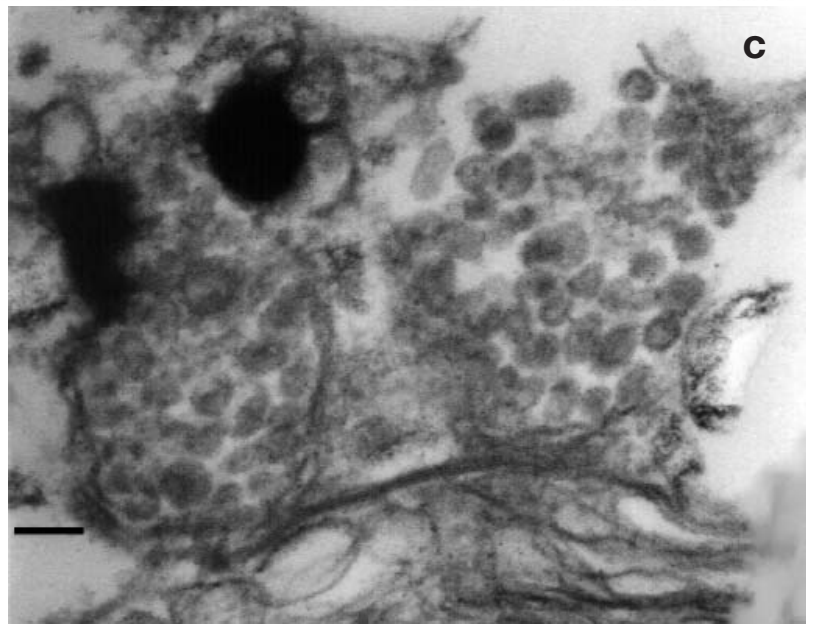

This could indicate the presence of different zooxanthella types in Anemonia viridis, with varying degrees of susceptibility to infection. Evidence for different types of zooxanthellae in A. viridis is equivocal (Bythell et al. 1997, Davy et al. 1997a,b), but the simultaneous presence of different zooxanthella taxa has been observed in corals (Rowan \& Knowlton 1995, Rowan et al. 1997).

Previous reported attempts to isolate viruses from marine symbiotic algae have been few and unsuccessful. O'Brien et al. (1984) looked at thin sections of dinoflagellates (zooxanthellae) and Chlorella-like algae (zoochlorellae) symbiotic with the temperate sea anemone Anthopleura xanthogrammica, expecting to find viruses. Their failure to observe any led them to believe that the absence of lytic viruses was a fundamental distinction between marine and freshwater algal-invertebrate symbiosis, though it should be noted that these authors did not look at environmentally stressed individuals. In contrast, viruses have been observed in free-living marine dinoflagellates (cf. symbiotic dinoflagellates). Franca (1976) reported the presence of numerous small virus-like particles (VLPs), approximately $35 \mathrm{~nm}$ in diameter, in the cytoplasm of Gyrodinium resplendens. Sicko-Goad \& Walker (1979) found much larger VLPs $(385 \mathrm{~nm})$ in the freshwater 
dinoflagellate Gymnodinium uberrimum, which were observed budding from a vesicular viroplasmic area. These workers suggested that a latent infection had been induced by changing environmental conditions (not specified).

As stated previously, high seawater temperatures have been blamed for major coral bleaching events (Anderson 1999, Harvell et al. 1999, Pockley 1999, 2000). Given the close taxonomic relationship between the zooxanthellae in Anemonia viridis and those of reef corals (Bythell et al. 1997, Davy et al. 1997b), our novel findings raise the possibility that viral infection contributes to bleaching events on coral reefs. We consider this to be an important topic for future research.

Acknowledgements. This research was supported by the Natural Environmental Research Council through a grant in aid awarded to the Marine Biological Association of the UK (MBA) and through the Applied Marine Science Masters programme at the Institute of Marine Studies, University of Plymouth. W.H.W is a MBA research fellow.

\section{LITERATURE CITED}

Anderson I (1999) Great barren reefs. New Sci 163(2194):12

Banin E, Khare SK, Naider F, Rosenberg E (2001) Proline-rich peptide from the coral pathogen Vibrio shiloi that inhibits photosynthesis of zooxanthellae. Appl Environ Microbiol 67:1536-1541

Bergh O, Borsheim KY, Bratbak G, Heldal M (1989) High abundance of viruses found in aquatic environments. Nature 340:467-468

Bratbak G, Wilson WH, Heldal M (1996) Viral control of Emiliania huxleyi blooms. J Mar Syst 9:75-81

Bythell JC, Douglas AE, Sharp VA, Searle JB, Brown BE (1997) Algal genotype and photoacclimatory responses of the symbiotic alga Symbiodinium in natural populations of the sea anemone Anemonia viridis. Proc R Soc Lond B 264:1277-1282

Davies PS (1992) Endosymbiosis in marine cnidarians. In: John DM, Hawkins SJ, Price JH (eds) Plant-animal interactions in the marine benthos. Clarendon Press, Oxford

Davy SK (1994) The specificity of temperate anthozoandinoflagellate symbioses. PhD thesis, University of Wales

Davy SK, Lucas IAN, Turner JR (1997a) Uptake and persistence of homologous and heterologous zooxanthellae in the temperate sea anemone Cereus pedunculatus (Pennant). Biol Bull 192:208-216

Davy SK, Turner JR, Lucas IAN (1997b) The nature of temperate anthozoan-dinoflagellate symbioses. Proc 8th Int Coral Reef Symp 2:1307-1312

Edgar RS, Lielausis I (1964) Temperature sensitive mutants of phage T4D: their isolation and genetic characterisation. Genetics 49:649-662

Franca S (1976) On the presence of virus-like particles in the dinoflagellate Gyrodinium resplendens (Hulburt). Protistologica 12:425-430

Fuhrman J (1999) Marine viruses and their biogeochemical and ecological effects. Nature 399:541-548

Gates RD, Baghdasarian G, Muscatine L (1992) Temperature stress causes host cell detachment in symbiotic cnidarians: implications for coral bleaching. Biol Bull 182:324-332
Harvell CD, Kim K, Burkholder JM, Colwell RR, Epstein PR, Grimes DJ, Hofmann EE, Lipp EK, Osterhaus ADME, Overstreet RM, Porter JW, Smith GW, Vasta GR (1999) Emerging marine diseases-climate links and anthropogenic factors. Science 285:1505-1510

Hoegh-Guldberg O (1999) Coral bleaching, climate change and the future of the world's coral reefs. Mar Freshw Res 50:839-866

Hoffman LR, Stanker LH (1976) Virus-like particles in the green alga Cylindrocapsa. Can J Bot 54:2827-2841

Iglesias-Prieto R, Matta JL, Robins WA, Trench RK (1992) Photosynthetic response to elevated temperature in the symbiotic dinoflagellate Symbiodinium microadriaticum in culture. Proc Natl Acad Sci USA 89:10302-10305

Jones RJ, Ward S, Amri AY, Hoegh-Guldberg O (2000) Changes in quantum efficiency of Photosystem II of symbiotic dinoflagellates of corals after heat stress, and of bleached corals sampled after the 1998 Great Barrier Reef mass bleaching event. Mar Freshw Res 51:63-71

Kushmaro A, Rosenberg E, Fine M, Loya Y (1997) Bleaching of the coral Oculina patagonica by Vibrio AK-1. Mar Ecol Prog Ser 147:159-165

Muscatine L (1990) The role of symbiotic algae in carbon and energy flux in reef corals. In: Dubinsky Z (ed) Coral reefs. Elsevier, Amsterdam

O'Brien TL, Macleod R, Maclean MC (1984) Absence of lytic virus in two species of symbiotic algae within the sea anemone Anthopleura xanthogrammica (Coelenterata: Anthozoa). Trans Am Microsc Soc 103:228-232

Obura DO (1999) Status report Kenya. CORDIO: status reports and project presentations. p 33-36

Pockley P (1999) Global warming could kill most coral reefs by 2100 . Nature 400:98

Pockley P (2000) Global warming identified as main threat to coral reefs. Nature 407:932

Rajasuriya A, Hassan Maniku M, Subramanian BR, Rubens J (1999) Coral reef ecosystems in South Asia. CORDIO: status reports and project presentations. p 11-24

Rowan R, Knowlton N (1995) Intraspecific diversity and ecological zonation in coral algal symbiosis. Proc Natl Acad Sci USA 92:2850-2853

Rowan R, Knowlton N, Baker A, Jara J (1997) Landscape ecology of algal symbionts creates variation in episodes of coral bleaching. Nature 388:265-269

Scanlan DJ, Wilson WH (1999) Application of molecular techniques to addressing the role of $\mathrm{P}$ as a key effector in marine ecosystems. Hydrobiologia 401:149-175

Sicko-Goad L, Walker G (1979) Viroplasm and large viruslike particles in the dinoflagellate Gymnodinium uberrimum. Protoplasma 99:203-210

Wang JT, Douglas AE (1998) Nitrogen recycling or nitrogen conservation in alga-invertebrate symbiosis? J Exp Biol 201:2445-2453

Warner ME, Schmidt GW, Fitt WK (1999) Damage to photosystem II in symbiotic dinoflagellates: a determinant of coral bleaching. Proc Natl Acad Sci USA 98:8007-8012

Wilcox RM, Fuhrman JA (1994) Bacterial viruses in coastal seawater: lytic rather than lysogenic production. Mar Ecol Prog Ser 114:35-45

Wilson WH, Joint IR, Carr NG, Mann NH (1993) Isolation and molecular characterisation of five marine cyanophages propagated on Synechococcus sp. strain WH7803. Appl Environ Microbiol 59:3736-3743

Wilson WH, Turner S, Mann NH (1998) Population dynamics of phytoplankton and viruses in a phosphate limited mesocosm and their effect on DMSP and DMS production. Estuar Coast Shelf Sci 46(Suppl A):49-59 